\title{
Social embeddedness in a harmonized Europe: the social networks of European migrants with a native partner in Belgium and the Netherlands
}

\author{
SUZANA KOELET, ${ }^{*}$ CHRISTOF VAN $\mathrm{MOL}^{\dagger}$ \\ AND HELGA A. G. DE VALK \\ *Free University Brussels, Pleinlaan 5, \\ 1050 Brussels, Belgium \\ ${ }^{\dagger}$ (corresponding author) Netherlands Interdisciplinary Demographic Institute, \\ Lange Houtstraat 19, 2511 CV, The Hague, Netherlands \\ mol@nidi.nl \\ ${ }^{\ddagger}$ Netherlands Interdisciplinary Demographic Institute and \\ Free University Brussels
}

\begin{abstract}
Although intra-European migration is often considered relatively easy to realize given European citizens' right to freedom of movement, settlement in another European country can still be experienced as socially disruptive. Insights in the insertion processes of European migrants, nevertheless, remain rather scarce. In this study, we analyse the social networks of European nationals with a native partner in Belgium and the Netherlands. The analysis is based on survey data from the EUMARR project $(n=576)$. First, we study the size and composition of European migrants' local family and friendship networks, and the frequency of contact with these networks. Second, we connect intra-EU movers' insertion routes to investments in transnational networks in their home country. The results reveal how size, composition and contact with the local and transnational network change over time. Children help to maintain contact with both the local and transnational family network and form a bridge for parents to meet own friends in the host country. Moreover, having own friends and own family around matters for contact frequency with the local networks.
\end{abstract}

Keywords BELGIUM, INTRA-EUROPEAN MOBILITY, NETHERLANDS, SOCIAL NETWORKS, SOCIAL EMBEDDEDNESS, TRANSNATIONAL NETWORKS, UNION FORMATION

The number of Europeans living in another European member state significantly increased in recent decades, from 5.5 million in 1990 to 13.7 million in 2014 (CastroMartín and Cortina 2015). Today, European migrants form an important share of the foreign population in many European countries, representing about 40 per cent of the 
total migrant population in the European Union (EU) (Castro-Martín and Cortina 2015). Furthermore, reasons for migrating within the EU are becoming increasingly diverse (King 2002). Apart from economic motivations, people now increasingly move in the EU for education, lifestyle, retirement, love and relationships (Gilmartin and Migge 2015; Recchi 2008; Santacreu et al. 2009; Verwiebe 2014). Nevertheless, migration scholars have largely neglected intra-European migration, except East-West migration, and the migration experience of European immigrants has yet received surprisingly little academic attention (Castro-Martín and Cortina 2015; Polek et al. 2010; Recchi 2015). This is partly because intra-European migration movements are generally evaluated in more positive terms. Intra-EU mobility would, for example, enhance a more integrated and efficient European economy (Recchi 2015) and increase Europe's competitiveness among global knowledge economies (Van Mol 2014). Furthermore, the movement of European citizens within the European Union is easier to realize than migration from outside the EU. European citizens' right to freedom of movement means that they are not subjected to, for example, visa legislations (Favell 2008; Recchi 2015). Consequently, they might face fewer institutional barriers. Nevertheless, intraEuropean migration can also be experienced as socially disruptive, as it implies a reformulation of movers' social networks in the countries of origin and destination. The few existing studies on specific groups of intra-EU movers such as highly skilled migrants and students, indeed suggest that these international migrants also experience adjustment processes and encounter significant obstacles when trying to settle in the host country (Ciupijus 2011; Favell 2008; Kennedy 2008; Ryan and Mulholland 2014a and 2014c; Van Mol and Michielsen 2015).

Considering the longstanding interest in migration sociology in the role of social networks in migration processes (Petersen 1958; Thomas and Znaniecki 1918), it is somewhat surprising that intra-EU movers' social networks have not yet been subject of study. Most European studies consider the migration and insertion processes of nonEU migrants (van Tubergen 2014), thus neglecting the substantial number of intra-EU movers. Although in recent years some progress has been made in advancing our understanding of the functioning of European migrants' social networks (Ryan 2007; Ryan and Mulholland 2014b, 2014c; Van Mol and Michielsen 2015), our knowledge of this group of migrants is still extremely limited. Moreover, the vast majority of studies into migration and social networks focus on the impact of social networks on migration decisions (Boyd 1989; Massey and Espinosa 1997), or the functions that social networks fulfil in the society of arrival in terms of, for example, finding a job (Cook et al. 2011) and housing (Gill and Bialski 2011). There has been less attention paid to the distribution of social capital, as well as access to, size and composition of social networks across different ethnic groups (van Tubergen 2014; Völker et al. 2008).

Our aim in this article is to improve our understanding of intra-European migrants and their social embeddedness, through an analysis of the local and transnational social networks of intra-EU movers with a native partner in Belgium and the Netherlands. Native partners can provide the migrant with more interethnic contacts (Martinovic et al. 2009; Schaeffer 2013), as they are the link to in-laws and host country friends (Lubbers et al. 2010). The native partner can thus constitute a privileged bridge towards 
the society of destination, representing easy and quick access to the social networks and economic resources of that society (Gaspar 2009). Drawing on a unique survey on European bi-national couples, EUMARR, we aim to advance scientific knowledge in three ways. First, we extend the study of migrant social network formation to the context of intra-EU mobility. Second, we investigate the relationships between network size, network composition, and frequency of contact with the local and transnational networks. Third, we analyse local and transnational family and friendship networks simultaneously. This is important, since 'it is very difficult to grasp the functional and structural features of one set of relationships without information on the other' (Widmer 2004: 357). Furthermore, the EUMARR-survey allows one to differentiate throughout the analyses between both a migrant's own family and in-laws as well as personal friendships and friends met through the partner. As such, the analysis sheds light on different network types and their interrelations.

\section{Background}

\section{Social embeddedness and social network reconstruction in a migration context}

Korinek et al. (2005) define social embeddedness as the social relationships that foster a sense of rootedness and integration. Many authors have pointed to the positive effects of social embeddedness (Coleman 1988; Granovetter 1992; Korinek et al. 2005; Langford et al. 1997; Portes and Sensenbrenner 1993). Socially embedded individuals can rely on group solidarity and informal social support for the pursuit of their personal goals. The social relationships in which they are engaged ensure access to practical resources. Social embeddedness, furthermore, is considered a necessary condition for an individual's successful personal development, social integration and political participation in society. Nevertheless, several authors also pointed to the flipside of social embeddedness. Possible negative consequences of social embeddedness are linked to social pressure and social control (Breton 1964; Portes and Sensenbrenner 1993). However, it should be noted that positive and negative consequences of social embeddedness often exist alongside, even within, one ethnic community, due to the existence of subgroups within such communities (Roggeveen and Van Meeteren 2013).

Migration can be expected to have a disruptive effect on social embeddedness (Coleman 1990). On the one hand, existing social networks become spatially stretched and fragmented when individuals move to another country, and new social networks are generally constructed in the society of arrival. These new networks fulfil an important function, operating 'as a temporary "substitute" for family and friends left behind" (Kennedy 2004: 176). On the other hand, migration can strengthen social ties, for migrants' existing networks do not necessarily dissolve but are rather preserved in a modified form (Levitt 2001). Networks are hence no longer localized, and migrants become embedded in a transnational network where solidarity and trust operate, linking multiple localities (Zontini 2004). With increased possibilities of communication across international borders and relatively cheap and accessible transport within Europe, there are abundant chances of maintaining spatially fragmented social networks across Europe. 
In a migration context, contact with the majority population is often considered crucial for the social integration of non-nationals in the host society (Völker et al. 2008). Putnam (2000) differentiated between 'bonding' and 'bridging' social capital and pointed to the importance of bridging ties when studying immigrants' integration. Ties with the local population in migrants' social network would serve as a bridge to integration and would result in a better position in the host society (de Miguel Luken and Tranmer 2010). Nevertheless, migrants often face significant problems in establishing meaningful links with the local population (Ryan 2011). Most studies into social network composition of migrants focus on migrants arriving alone or with their family. Little is known, however, about the social network reconstruction of international migrants who have a native partner, and even less about intra-EU movers who are in a union with a native. As a result, the overview of relevant literature for studying European migrants' social networks in the next sections of this article is based on social network studies conducted among general as well as migrant populations.

\section{The evolution of local and transnational social networks in a migration context}

In the initial phases of migration, contacts with family and friends in the home country (Levrau et al. 2014) and co-ethnics in the destination country (Gill and Bialski 2011) are generally important for both practical and emotional support. During the first phases of migration, moreover, the overall social network generally shrinks (Bidart and Lavenu 2005) and contact with the local population often remains limited (Domínguez and Maya-Jariego 2008). Over time, however, networks evolve, as the time an individual spends in a certain context influences the probability of establishing, continuing, and discontinuing social relationships (Mollenhorst et al. 2014). The longer a migrant stays in the host country, the more likely he or she is to establish new friendships, so over time social networks become heterogeneous, including members of the local population (Domínguez and Maya-Jariego 2008; Kennedy 2008; Lubbers et al. 2010). How migrants balance contacts within local and transnational networks is less clear. With an increasing share of autochthonous friends, EU-movers might become increasingly fluent in the host country language (Martinovic et al. 2009; Vervoort et al. 2011). This increased fluency in the host country language may stimulate and facilitate contact with other members of the host population (Martinovic 2013; Martinovic et al. 2009). An increasing share of native friends might thus be related to more frequent contact with family and friends in the host country.

Furthermore, migration duration shows to be linked to a decrease in the frequency of contact with social networks in the home country (Hedberg and Kepsu 2008; Levrau et al. 2014). Migration particularly affects dispersed friendships and extended family ties (Eve 2008; Mollenhorst et al. 2014; Viry 2012), mainly because maintaining relations requires an active effort and time (Ryan and Mulholland 2014b). Earlier work showed that "the combination of the obligation to help kin, and the high level of structural embeddedness means that kin are both cognitively and time-wise less demanding relationships to maintain than non-kin relationships' (Roberts et al. 2009: 139), especially in a migration context. Research among European migrants confirms this, as 
intra-EU movers are shown to be particularly likely to stay in touch with their close family and friends (Morosanu 2013; Ryan and Mulholland 2014a), and the longer they live abroad, the more the connections with the home country diminish (Morosanu 2013).

Migration duration, however, also influences the composition of familial networks in the host country. The longer a migrant stays in a country, the more likely there is to be a larger family network present in the host country (Boyd 1989), for migrants often tend to reunify their families, or start forming families themselves. Furthermore, when a large group of kin (relatives from the home country as well as in-laws) is geographically close, there is logically more interaction with this group (Mulder and Cooke 2009; Schweizer et al. 1998). In addition, when the core family is present in the host country, contact with the transnational network is shown to decrease (Rodríguez and Egea 2006). Conversely, migrants who do not dispose of kin relationships in the host country rely more on ethnic networks, which can act as a substitute (Nee and Sanders 2001).

\section{Relationship and background characteristics}

Several background characteristics found in the literature are shown to be related to the size and composition of individuals' social networks.

First, several studies indicate that children often play a bridging role in establishing contact with the local population, as they provide extra meeting opportunities at, for example, school gates or play grounds (Levrau et al. 2014; Ryan 2007, 2011; Ryan and Mulholland 2014b; Ryan et al. 2008; Schaeffer 2013). Nevertheless, contrasting findings have also been reported. For example, a case study of French migrants in London by Ryan and Mulholland (2014c) showed that children can also curb interaction, as some parents deliberately establish contacts with other co-national parents. Furthermore, parents also become more engaged in friendship networks within the neighbourhood (Kalmijn 2012; Moore 1990). As they become involved in new neighbourhood networks and have more opportunities to meet fellow parents through their children's contacts (Munch et al. 1997), we can expect a positive relationship between the number of children, the size of a friendship network and the frequency of contact with friends in the host society. Furthermore, given the establishment of such new relationships, it can be expected that children increase the share of their own friends in the respondents' network. Furthermore, it has been reported that children increase contact with their family (Bost et al. 2002; Fischer and Oliker 1983; Munch et al. 1997) as the size of the nuclear family increases through the need for help with caring tasks (Kennedy 2008; Silverstein and Marenco 2001). In addition, parents often want the children to be in touch with their roots (Levrau et al. 2014; Rodríguez and Egea 2006).

Second, relationship duration can also be expected to play a role in the social network composition of intra-EU movers. After all, it has been demonstrated that there is a negative association between the duration of a marriage and the size of a friendship network (Fischer and Oliker 1983; Wellman et al. 1997). Over the course of a life, the friendship networks of couples will shrink and overlap, as partners provide access to each other's network (Bidart and Lavenu 2005; Kalmijn 2003; Viry 2012). 
Based on this literature, we expect to find empirical evidence for the model presented in Figure 1. This model forms the basis for our empirical analyses presented hereafter.

Figure 1: Expected paths for the structure of and frequency of contact with local and transnational networks of family and friends of intra-EU movers

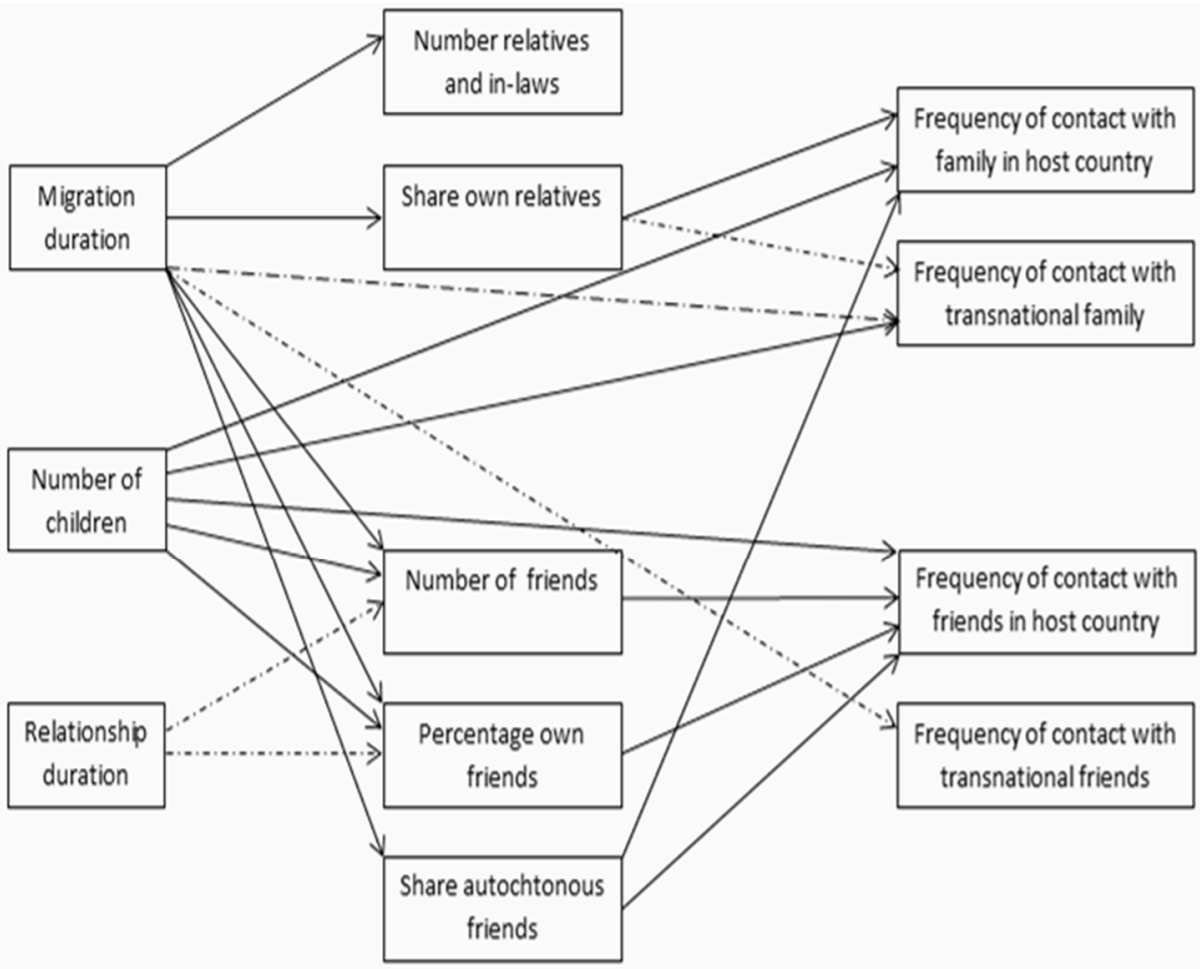

$\longrightarrow$ Positive correlation

$\cdots$ Negative correlation

\section{Methods and data}

\section{Data}

This article uses the international comparative EUMARR-survey data. This unique survey collected data among European bi-national couples and (native) uni-national couples in Belgium, the Netherlands, Spain and Switzerland in 2012-13. The EUMARR project aims to measure trends in bi-national unions between citizens of the European Union and examines the extent to which these bi-national couples have a different lifestyle and worldview. Therefore, the survey collected data on respondents' personal and family background, international experiences, social networks, tastes, identity, and political and social engagement. Bi-national couples were defined as couples consisting of one native and one European partner; uni-national couples are 
couples composed of two native partners. All respondents in the survey were aged between 30 and 45 at the time of the survey (with an average age of 38 years). The choice for this particular age range was informed by the aim to have a homogeneous sample, including only respondents who started their unions well after the establishment of freedom of movement as a fundamental right for European citizens. This age range also meant that migration histories and experiences were more recent and thus less affected by recall error than would have been the case for older people. The lower age limit was established for the different countries in the project because this is when most individuals have entered a stable union but when levels of repartnering are still limited.

In this article, we use pooled data from two neighbouring countries, namely Belgium $(n=805)$ and the Netherlands $(n=918)$. The data were collected through online and paper questionnaires in four internationally oriented cities - The Hague and Amsterdam in the Netherlands, and Antwerp and Brussels in Belgium. The selection of urban settings was motivated by concerns of comparability in the international project, as well as the fact that more European migrants live in large cities. The Antwerp sample and both Dutch samples were drawn randomly from the respective Municipal Population Registers; the Brussels sample from the National Population Register. For each sample, we based our selection of married and cohabiting couples on the current nationality and age of the partners, after which one partner per couple was randomly chosen as a (potential) respondent. Response rates across both countries were roughly similar, namely 32.2 per cent in Belgium, and 37.1 per cent in the Netherlands.

Because we aim to unravel the structure of the social networks of European individuals who migrated to another country, a distinction based on country of birth rather than nationality is relevant. Therefore, we focus on European nationals in binational couples who are foreign born, and whose local partner is native born $(n=244$ for Belgium and $n=332$ for the Netherlands). The mean age of migration for the foreign-born European nationals is 26, even if some moved to Belgium as a child. The Europeans in the Belgian survey belong to six nationalities, namely Dutch, French, German, Spanish, Italian, and Polish, representing the most frequent nationalities in European bi-national marriages in Belgium. The Dutch survey had no restriction on (European) nationality in the sample. Here, German, English, French, Belgian, Spanish, Italian, and Polish account for 70 per cent of all European nationals in the survey.

Some 66 per cent of the European migrants in our sample are women (58 per cent in the Belgian survey and 72 per cent in the Dutch survey). The sample is also relatively well educated: 64 per cent of the respondents in the Belgian survey have at least a master's degree. In the Dutch survey, 57 per cent obtained such degrees. Although no register data on education of European migrants are available with which to compare our sample composition, relatively high levels of education are also reported in other surveys that include European migrants. For example, results of the Labour Force Survey in Belgium show that 45 per cent of mobile Europeans finished tertiary education compared with 26 per cent of the native population (Martiniello et al. 2010), and a survey on the effects of EU-migration to Amsterdam reports that 68 per cent of EU migrants finished tertiary education (Booi et al. 2013). In addition, it has been 
reported that overall, mobile citizens from the EU-15 have higher educational levels compared with the national averages in both their countries of origin and destination (Recchi 2015). Finally, 83 per cent of the European migrants in our sample are employed.

\section{Variables}

The variables used in the analysis can be divided into three categories, namely (1) migration; (2) couple characteristics; and (3) network characteristics.

The migration history is covered by a continuous variable indicating the number of years since migration to the host country.

The couple characteristics include two continuous variables -the number of years since the start of the relationship and the number of children in the current relationship.

Given our research question we focus on different dimensions of the respondents' networks in our analyses. A first continuous variable indicates the number of family members living in the host country. Family members are defined as siblings, parents, grandparents, uncles, aunts, cousins, nephews, and nieces of the respondents or the partner. The variable has an upper limit of 'more than 10'. A second variable indicates the share of own relatives in this local family network in percentages.

Several variables measure the local friendship network. A first continuous variable indicates the total number of close friends in the host country with an upper limit of ' 11 or more friends'. Close friends are defined as people with whom one feels at ease, with whom one can talk to about what is on one's mind, or call up for help. A second variable indicates the percentage of own friends among the core friendship group, pointing to friends who were not met via or introduced by the partner. Respondents had to provide this information for a maximum of five of their closest friends. A third variable indicates the percentage of native friends among the core friendship group, measured by the country of birth. We do not use the distinction between co-ethnic friends and friends of other foreign origin here, as friendship networks of intra-EU movers appear to evolve around people in the same situation, not necessarily taking into account ethnicity as a criterion for inclusion in the social network (Morosanu 2013). We do, however, take the share of native friends in the local friendship network into account as such relationships often prove difficult to establish (Van Mol and Michielsen 2015).

Finally, we include three factor score scales, indicating frequency of contact with the different networks, based on five items (four for transnational networks, three for local networks), measuring (1) transnational visits; (2) received transnational visits, (3) face-to-face contact, (4) telephone contact and (5) written contact. Respondents could rate each of these items from 1 'rarely or never' to 8 'daily'. The inclusion of diverse modes of contact is essential, as alternatives to face-to-face interactions are an important way of keeping in touch with family and friends (Widmer 2004). A first score indicates frequency of contact with the local family network (Cronbach $\alpha=.78$ ), a second frequency of contact with the transnational family network (Cronbach $\alpha=.74$ ), a third with the local network of friends (Cronbach $\alpha=.82$ ), and a fourth with the transnational network of friends (Cronbach $\alpha=.69$ ). 


\section{Analytic strategy}

We use structural equation modelling (path analysis) to analyse the social networks of intra-EU movers in a binational union. These models allow one to study relationships between (1) the local network of family and the local network of friends of European migrants in the migration country; (2) the different dimensions of these local social networks (size, composition and frequency of contact); and (3) their links with the transnational network in the country of origin. The frequency of contact with the different local and transnational networks is interrelated and explained as a function of time since migration, and characteristics of the migrants' relationship (number of children and duration of the relationship).

We use the correlation matrix between the different variables as input for our model in IBM SPSS Statistics Amos 22. This allows the model to treat missing values pairwise. In order to produce appropriate results, data must be missing completely at random. This means that the missing values must be unrelated to the observed values. In our model, composition variables such as share of relatives, share of own friends or share of native friends, are missing by design in the sense that they are missing in the case of respondents who reported no family members ( 4 per cent) or no friends ( 8 per cent). Also, the frequency of contact with the respective local networks is missing when there are no local family members or local friends. These missing data by design can be considered missing completely at random as the estimates from the observed data are expected on average not to be any different from what they would be if there were no missing data (see also Little et al. 2014). This is also the case for transnational contact. However, as we could not include information on the size of the transnational family network, or transnational network of friends in our model, but information is available on whether such a network exists or not, this extra information is included in the model by imputing the minimum value to the respective contact scale for those European migrants with no transnational family (4 per cent) or no transnational friends (11 per cent).

\section{Results}

\section{Descriptives}

We first present descriptive statistics of the variables included in the structural equation models. As Table 1 shows, the European migrants with a native partner in our sample have been residing in their destination country for an average of 13 years. The average number of local family members is nine. These local family members are mainly inlaws: the average share of own relatives in the local family network is only 10 per cent. Furthermore, intra-European migrants have on average six local friends. In their friendship network, 70 per cent are own friends, and 53 per cent are native individuals. The factor scales have per definition an average value of 0 , except for the scales indicating frequency of contact with transnational networks, since respondents with no transnational family or friends were attributed the minimum value on this scale. A review of the separate Likert-items to construct the scales (not in Table 1) reveals that face-to- 
face contacts with the local family network of relatives and in-laws are frequent. Nevertheless, 28 per cent reports meeting local relatives or in-laws less than once a month. Finally, 15 per cent of the respondents reported meeting their local friends less than once a month (not in Table 1).

Table 1: Descriptive statistics ( $n=570$; Source: EUMARR Belgian and Dutch survey)

\begin{tabular}{lrrrrr}
\hline Variable & \multicolumn{7}{c}{ Total } & & & \\
& X & s & $n$ & Min. & Max. \\
\hline Migration duration & 13.00 & 8.43 & 430 & 0 & 44 \\
Relationship duration (in years) & 10.35 & 5.36 & 570 & 1 & 29 \\
Number of children & 1.14 & 0.98 & 570 & 0 & 6 \\
Size local family network (relatives and in-laws) & 8.72 & 3.59 & 529 & 0 & 11 \\
Size local network of friends & 6.14 & 3.89 & 561 & 0 & 12 \\
Frequency contact & & & & & \\
$\quad$ with local family network & .00 & 1.00 & 533 & -2.33 & 2.50 \\
$\quad:$ with transnational family network (EU) & -.10 & 1.11 & 539 & -2.58 & 3.71 \\
$\quad:$ with local network of friends & .01 & 1.00 & 497 & -3.20 & 2.02 \\
$\quad:$ with transnational network of friends (EU) & -.27 & 1.20 & 541 & -2.36 & 4.53 \\
& \multicolumn{2}{c}{$\%$} & & & \\
Share own relatives in local family network & 9.59 & 507 & & \\
Share own friends in local network of friends & 70.17 & 541 & & \\
Share native friends in local network of friends & 52.90 & 557 & & \\
\hline
\end{tabular}

\section{SE path-analysis of the social networks of European migrants}

Figure 2 shows the results of the SE path-analysis based on the model presented in Figure 1. The path-model explains the frequency of local and transnational contact with family and friends. The goodness of fit indices show that the model fits the data well (see for example Hox and Bechger 2007). In the path diagram, we only included paths where $p<0.05$.

Figure 2 shows that the size and composition of European migrants' local networks clearly change over time. Local friendship and family networks become larger with longer residence in the host country (family: $\beta=.11$; friends: $\beta=.24$ ). Furthermore, the local networks become increasingly composed of more own relatives (compared with in-laws, $\beta=.59$ ) and more own friends (compared with friends met through the partner, $\beta=.25$ ) over time. Having more own friends and relatives in the local social networks also increases the overall frequency of contact with these networks. Our results further suggest that contact with the transnational networks of family and friends in the EU diminishes over time (respectively $\beta=-.23$ and $\beta=-.30$ ). Contrary to our expectations, we did not find an effect of the share of own relatives in the host 
country on contact frequency with the transnational family $(\beta=-.00 ; p=.23)$. This result indicates that having more relatives close-by is not related to less contact with the family in the home country. Finally, the longer a European migrant resides in the host country, the larger the share of native friends in the local friendship network $(\beta=$ .21). Based on the existing literature, we expected this would lead to closer contact with both the local family network and network of friends. While this holds true for contact with the local family network $(\beta=.15)$, a negative relationship is revealed between the share of native friends and with frequency of contact with friends in the host country $(\beta=-.14)$. As a result, the total effect of migration duration on contact with the local network of friends appears to be limited $(\beta=.05$, see Table 2$)$, and smaller compared with the total effect of migration duration on contact with the local family network $(\beta=.18)$.

Figure 2: SE path-analysis for frequency of contact with local and transnational networks of family and friends

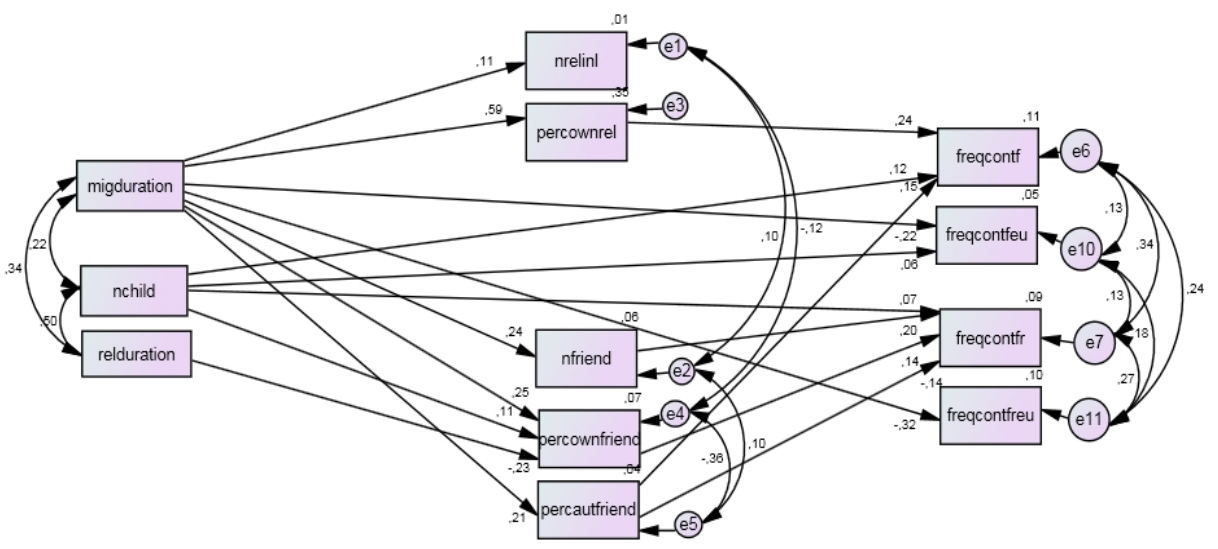

$\left(n=570, X^{2}=76.458, p=.000, \mathrm{CFI}=0.962, \mathrm{TLI}=0.931, \mathrm{RMSEA}=.044\right.$.

Source: EUMARR Belgian and Dutch survey.

Our model further confirms how characteristics of the relationship affect the size, composition and frequency of contact with the respective networks. First, the longer the duration of the relationship of European migrants, the lower the share of own friends (not met through the partner) in the local network of friends $(\beta=-.23)$. Contrary to our expectations, however, no effect was found on the size of the local friendship network $(\beta=.02, p=.65)$. Second, children show to positively affect the frequency of contact with both the local and transnational family network (respectively $\beta=.12$ and $\beta=.06$ ). Furthermore, having more children is related to having more own local friends $(\beta=.11)$ as well as more frequent contact with the local network of friends $(\beta=.07)$. Contrary to our expectations, however, we did not find an effect of the number of children on the size of the network of friends $(\beta=.08, p=.67)$.

Finally, considering the relation between size, composition and frequency of contact with the different networks, it can be noticed that it is not so much the size of the local 


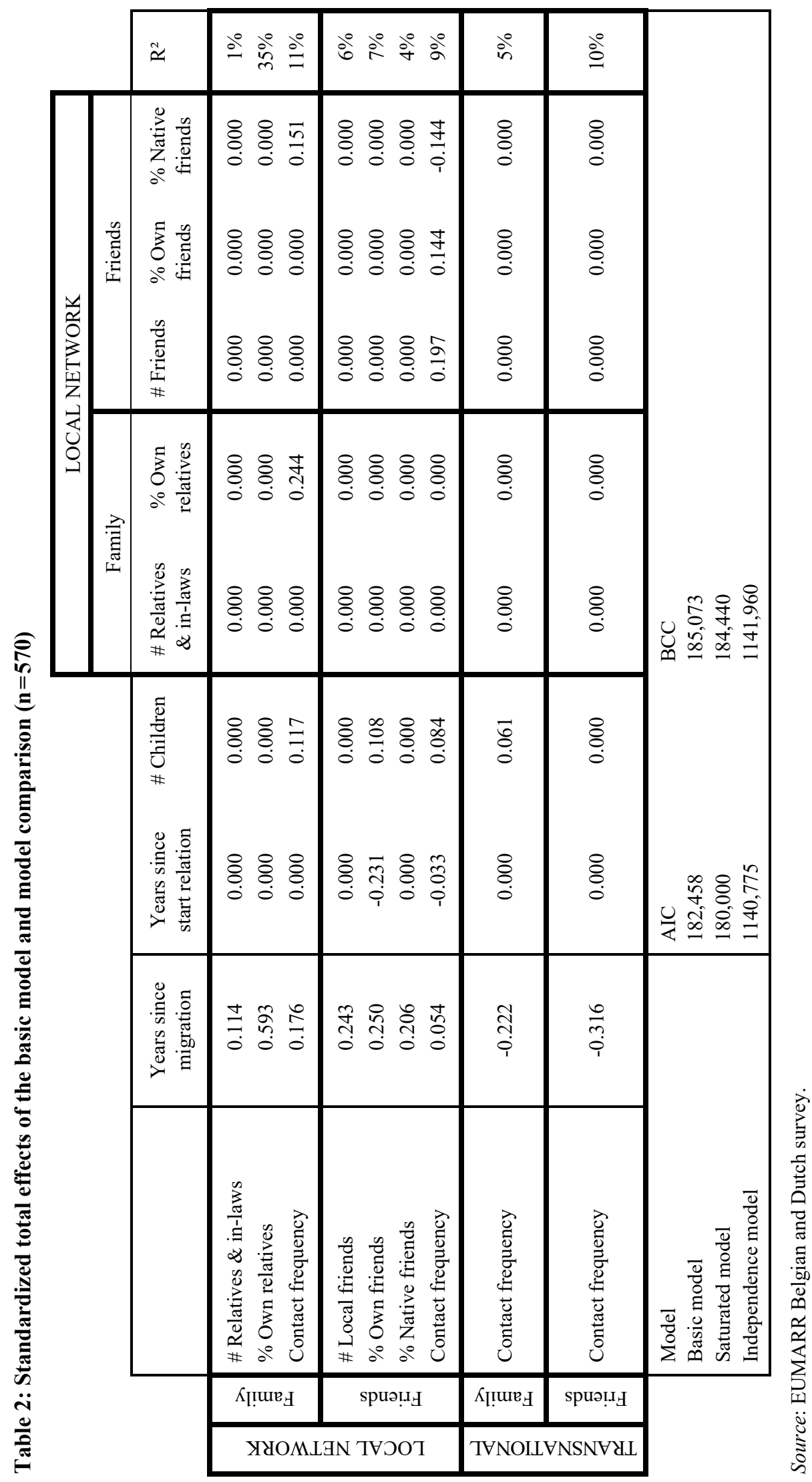


family network, but rather the composition (the number of local relatives) that translates into more frequent contact with the local family network $(\beta=.24)$. Furthermore, the size of the local family network has an impact on the size and composition of the local network of friends. A larger number of in-laws increases the size of the local network of friends $(\beta=.10)$ as well as the share of local friends met through the partner $(\beta=$ -.12). The effect of size and composition of the local network of friends is shown to be much broader. First, the size of the local friendship network has a positive impact on frequency of contact with the local network of friends $(\beta=.20)$. Second, disposing of more own local friends increases frequency of contact with the local friendship network $(\beta=.14)$. In contrast and as reported above, having more native friends has an opposite effect, as it decreases frequency of contact with the local friendship network $(\beta=-.14)$.

\section{Discussion and conclusion}

In this article, we explored a so far neglected topic in international migration research, namely the social networks of intra-EU movers. Our analysis focused on European migrants living in Belgium or the Netherlands who are in a union with a Belgian or Dutch partner. We aimed to advance our current understanding of social networks of intra-EU movers in three ways. First, we extended the study of migrant social network formation from non-EU migrants to intra-EU migrants. Second, we investigated the relationships between network size, network composition, and frequency of contact with both the local and transnational network. Third, we covered family and friendship networks.

First, our analysis revealed that over time, the composition of intra-EU movers' networks change. Gradually, these networks include more relatives as well as own and native friends. While having more own friends increases contact frequency with the local friendship network, we observed a negative relation between having native friends and contact frequency with this network. This might indicate that intra-EU movers often move within international communities in the country of destination, and more easily establish links with people in the same situation. Frequency of contact with local friends might thus be especially salient when local social networks are mainly composed of other international or co-national peers. This is plausible, for studies into the social networks of other migrant groups revealed that networks of co-national and international migrants are often important in the initial stages of migration (Gill and Bialski 2011). Of course, one should be aware that respondents in our sample who reside in the country longer might already be different in terms of other unobserved characteristics. Migration motives and union formation paths of more recent migrants are potentially different. Furthermore, a recent study on Bulgarian migrants in Spain (de Miguel Luken et al. 2015) suggested that while belonging to a mixed union implies a greater presence of natives in the personal network, these are mostly family members of the native partner and the effect on emotional proximity with natives is absent. Deepening our understanding of relations between European migrants and natives would thus be a logical next path to follow in future research. Furthermore, particularly contacts with transnational friendship networks seem to decline over time. The spatial stretch of a friendship network thus leads to a decrease in contact frequency. Maintaining such ties 
requires an active effort, and it can be hypothesized that migrants' physical absence hampers such maintenance, leading to a progressive decrease in contact frequency, even in the European context, wherein moving internationally is relatively easy and affordable. Surprisingly, our findings show that contact frequency with the transnational family network also declines over time. The wide geographical spread of our sample might explain this finding. It is imaginable, for example, that those who move to a neighbouring country have more opportunities to travel frequently and relatively cheaply to their home country for maintaining social ties compared with those who have to travel over larger distances. While such analysis falls beyond the scope of this article, and cannot be conducted with our data due to the relatively limited numbers of respondents per origin group, it offers an interesting venue for future research. Furthermore, although contact frequency with the transnational family might decrease, this does not necessarily mean that relatives do not maintain an important role in providing emotional support (Rooyackers et al. 2014). Last, parallel with migration duration, the likelihood of family reunification in the host country might also increase, potentially explaining these results. Unfortunately, our data do not allow us to shed light on these important issues and the processes of reunification among European migrants are so far unstudied.

Second, and consistent with previous studies, we showed that having children has a positive impact on the frequency of contact with the local and transnational family network. This shows the important role that children play for couples at this stage of their lives. Furthermore, it indicates that parents are particularly keen to maintain family ties and keep their children connected with both the place of residence and the place of origin. Studies on the children of non-Western immigrants indicate that balancing these two is crucial for identity development among this group. While there is no effect on the size of the network of friends, the share of own friends in the network and (directly and indirectly) the frequency of contact with the local network of friends do rise with the number of children. A similar pattern is found for duration of the relationship: while relationship duration does not affect the size of the local friendship network, it does affect the composition (and therefore indirectly the frequency of contact with the local network). The longer the relationship lasts, the fewer own friends European migrants are shown to have among their core friendship group. This finding illustrates the relevance of including different aspects, composition, and size when studying the social networks of (European) migrants.

Third, our study reveals that it is not so much the size of the local family network, but rather the fact of having own relatives nearby that matters for contact with the local family network. Also for friends, our analysis showed that having own friends who are not met through the partner are important for closeness of contacts (besides having many friends). Otherwise, the analysis indicated that having more relatives around does not necessarily lead to smaller local friendship networks. Actually, more contact with the local family network is related to more contact with the local friendship network. Consequently, intra-EU migrants do not seem to rely primarily on family or friends in the destination country. Therefore, it appears to be rather an accumulation than a compensation effect: some people are more sociable and have a wider network to rely on, whereas others have a more limited social circle. This suggests that the study should 
include more personal traits to reveal why some individuals have a more extensive social network, which has a potential impact on both the wellbeing and position of an individual in society. In line with this, we revealed a significant relationship between the share of native friends in the local friendship network and the frequency of contact with the local family network. This might be interpreted as more frequent contacts of the European migrant with his or her local in-laws will lead to more native friends, which would indicate that in-laws can figure as bridging persons towards the host society as well. On the other hand, this can also indicate that the respondents consider some of the in-laws as actual friends. Another explanation might be that those with more native contacts establish links with in-laws more easily because of their enhanced knowledge of local customs and the host country's language through their network of native friends. In any case, both own family and in-laws are shown to be important in people's lives, although the levels of contact and exchange might differ between them (Rossi and Rossi 1990; Verweij and Kalmijn 2004) as well as across the life cycle (Van der Pers et al. 2015). In a context of intra-EU mobility, this closeness is clearly challenged. We are still to understand the effects of migration on families left behind in an EU context. Prospective longitudinal research might be helpful for unravelling the causal mechanisms behind these interpretations as well as better capture the role that family and in-laws play in European migrants' lives.

Although our study advanced current understandings of European migrants' social networks, some limitations should be mentioned. As we only dispose of cross-sectional data capturing retrospective longitudinal information, we were unable to observe factual changes in the structure and composition of intra-EU movers' social networks. Future studies into the effects of intra-EU mobility on social network structure and evolution might therefore benefit from longitudinal data, allowing one to unravel how social structures change over time. Second, we investigated the social networks of intraEU movers through bi-national couples with a privileged bridge towards the receiving society. Future research among intra-EU movers without such a privileged connection can shed more light on the dynamics of the social network formation of European migrants. Finally, future studies could better capture social networks and their differences in terms of size, composition, and contact according to countries of origin and destination, uncovering the heterogeneity and contextual embeddedness of social network formation within Europe. Qualitative studies have the potential to indicate what bonds are maintained and how. On a similar note, it would be promising to compare European binational couples that have a native partner with binational couples that have a non-EU partner, as well as with European binational couples in which both partners are European migrants. Such comparisons would allow one to dig deeper into the specificities of the social network formation of intra-EU movers.

In conclusion, we reported a considerable variability in the social networks of intra-EU movers. Our findings revealed that not only the size of social networks should be taken into account, but also the composition and frequency of contact with these respective networks for sketching a nuanced picture of the relevance of social networks in people's lives. In any case, establishing contact with the local population as well as maintaining contact with social networks at origin is not self-evident, even for intra-European movers. 


\section{Acknowledgements}

This article is part of the Dutch contribution to the collaborative research project EUMARR, funded within the framework of the 2009 ERCP finance programme of the European Science Foundation (project number 09-ERCP-044, NWO finance number 461-09-507, FWO finance number G.0994.10N: 'Towards a European society: single market, bi-national marriages, and social group formation in Europe'). The contribution of Helga de Valk was part of (and funded by) the European Research Council Starting Grant project (no. 263829) 'Families of migrant origin: a life course perspective'.

\section{References}

Bidart, C. and D. Lavenu (2005) 'Evolutions of personal networks and life events', Social Networks, 27 (4), 359-76, doi: 10.1016/j.socnet.2004.11.003.

Booi, H., E. Lindeman and J. Slot (2013) Monitor EU-migranten, Amsterdam: Bureau voor Onderzoek en Statistiek, available at: www.ois.amsterdam.nl/pdf/2014_monitor EU_mig ranten 2013.pdf.

Bost, K. K., M. J. Cox, M. R. Burchinal and C. Payne (2002) 'Structural and supportive changes in couples' family and friendship networks across the transition to parenthood', Journal of Marriage and Family, 64 (2), 517-31, doi: 10.1111/j.1741-3737.2002.00517.x.

Boyd, M. (1989) 'Family and personal networks in international migration: recent developments and new agendas', International Migration Review, 23 (3), 638-70, doi: 10.2307/2546433.

Breton, R. (1964) 'Institutional completeness of ethnic communities and the personal relations of immigrants', American Journal of Sociology, 70 (2), 193-205, doi: 10.1086/223793.

Castro-Martín, T. and C. Cortina (2015) 'Demographic issues of intra-European migration: destinations, family and settlement', European Journal of Population, 31 (2), 109-25, doi: 10.1007/s10680-015-9348-y.

Ciupijus, Z. (2011) 'Mobile central eastern Europeans in Britain: successful European Union citizens and disadvantaged labour migrants?', Work, Employment and Society, 25 (3), 540-50, doi: 10.1177/0950017011407962.

Coleman, J. S. (1988) 'Social capital in the creation of human capital', American Journal of Sociology, 94, 95-120, doi: 10.1086/228943.

Coleman, J. S. (1990) Foundations of social theory, London: Harvard University Press.

Cook, J., P. Dwyer and L. Waite (2011) 'Good relations among neighbours and workmates? The everyday encounters of accession 8 migrants and established communities in urban England', Population, Space, and Place, 17 (6), 727-41, doi: 10.1002/psp.638.

de Miguel Luken, V. and M. Tranmer (2010) 'Personal support networks of immigrants to Spain: a multilevel analysis', Social Networks, 32 (4), 253-62, doi: 10.1016/j.socnet.2010.03.002.

de Miguel Luken, V., M. J. Lubbers, M. Solana Solana and D. Rodríguez-García (2015) 'Evaluation of the relational integration of immigrants in mixed unions based on an analysis of their personal networks', Revista Española de Investigaciones Sociológicas, 150, 151-72, doi: $10.5477 /$ cis/reis. 150.151 .

Domínguez, S. and I. Maya-Jariego (2008) 'Acculturation of host individuals: immigrants and personal networks', American Journal of Community Psychology, 42 (3-4), 309-27, doi: 10.1007/s10464-009-9259-3.

Eve, M. (2008) 'Some sociological bases of transnational practices in Italy', Revue européenne des Migrations internationales, 24 (2), 67-90, available at: https://remi.revues.org/4522.

Favell, A. (2008) Eurostars and Eurocities: free movement and mobility in an integrating Europe, Oxford: Blackwell Publishing.

Fischer, C. S. and S. J. Oliker (1983) 'A research note on friendship, gender, and the life cycle', Social Forces, 62 (1), 124-33, doi: 10.1093/sf/62.1.124. 
Gaspar, S. (2009) Mixed marriages between European free movers, CIES e-working paper 65, Lisbon: Centre for Research and Studies in Sociology, available at: http://goo.gl/Lq58Ud.

Gill, N. and P. Bialski (2011) 'New friends in new places: network formation during the migration process among Poles in the UK', Geoforum, 42 (2), 241-9, doi: 10.1016/ j.geoforum.2011.01.001.

Gilmartin, M. and B. Migge (2015) 'European migrants in Ireland: pathways to integration', European Urban and Regional Studies, 22 (3), 285-99, doi: 10.1177/0969776412474583.

Granovetter, M. (1992). 'Problems of explanation in economic sociology', in N. Nohria and R. G. Eccles (eds) Networks and organizations: structure, form and action, Cambridge, MA: Harvard Business School Press, 25-56.

Hedberg, C. and K. Kepsu (2008) 'Identity in motion: the process of Finland-Swedish migration to Sweden', National Identities, 10 (1), 95-118, 10.1080/14608940701819850.

Hox, J. J. and T. M. Bechger (2007) 'An introduction to structural equation modeling', Family Science Review, 11, 354-73, available at: www.joophox.net/publist/semfamre.pdf.

Kalmijn, M. (2003) 'Shared friendship networks and the life course: an analysis of survey data on married and cohabiting couples', Social Networks, 25 (3), 231-49, doi: 10.1016/S03788733(03)00010-8.

Kalmijn, M. (2012) 'Longitudinal analyses of the effects of age, marriage, and parenthood on social contacts and support', Advances in Life Course Research, 17 (4), 177-90, doi: 10.1016/j.alcr.2012.08.002.

Kennedy, P. (2004) 'Making global society: friendship networks among transnational professionals in the building design industry', Global Networks, 4 (2), 157-79, doi: 10.1111/ j.1471-0374.2004.00085.x.

Kennedy, P. (2008) 'The construction of trans-social European networks and the neutralisation of borders: skilled EU migrants in Manchester reconstituting social and national belonging', Space and Polity, 12 (1), 119-33, doi: 10.1080/13562570801969564.

King, R. (2002) 'Towards a new map of European migration', International Journal of Population Geography, 8 (2), 89-106, doi: 10.1002/ijpg.246.

Korinek, K., B. Entwisle and A. Jampaklay (2005) 'Through thick and thin: layers of social ties and urban settlement among Thai migrants', American Sociological Review, 70 (5), 779-800, doi: $10.1177 / 000312240507000503$.

Langford, C. P. H., J. Bowsher, J. P. Maloney and P. P. Lillis (1997) 'Social support: a conceptual analysis', Journal of Advances in Nursing, 25 (1), 95-100, doi: 10.1046/j.13652648.1997.1997025095.x.

Levitt, P. (2001) The transnational villagers, Berkeley: University of California Press.

Levrau, F., E. Piqueray, I. Goddeeris and C. Timmerman (2014) 'Polish immigration in Belgium since 2004: new dynamics of migration and integration?', Ethnicities, 14 (2), 303-23, doi: $10.1177 / 1468796813504100$.

Little, T. D., T. D. Jorgensen, K. M. Lang and E. W. G. Moore (2014) 'On the joys of missing data', Journal of Pediatric Psychology, 39 (2), 151-62, doi: 10.1093/jpepsy/jst048.

Lubbers, M. J., J. L. Molina, J. Lerner, U. Brandes, J. Ávila and C. McCarty (2010) 'Longitudinal analysis of personal networks: the case of Argentinean migrants in Spain', Social Networks, 32 (1), 91-104, doi: 10.1016/j.socnet.2009.05.001.

Martiniello, M., A. Rea, C. Timmerman and J. Wets (eds) (2010) Nouvelles migrations et nouveaux migrants en Belgique/Nieuwe migraties en nieuwe migranten in België, Gent: Academia Press.

Martinovic, B. (2013) 'The inter-ethnic contacts of immigrants and natives in the Netherlands: a two-sided perspective', Journal of Ethnic and Migration Studies, 39 (1), 69-85, doi: 10.1080/1369183X.2013.723249.

Martinovic, B., F. van Tubergen and I. Maas (2009) 'Dynamics of interethnic contact: a panel study of immigrants in the Netherlands', European Sociological Review, 25 (3), 303-18, doi: 10.1093/esr/jen049. 
Massey, D. S. and K. E. Espinosa (1997) 'What's driving Mexico-US migration? A theoretical, empirical and policy analysis', American Journal of Sociology, 102 (4), 939-99, doi: $10.1086 / 231037$.

Mollenhorst, G., B. Völker, B. and H. Flap (2014) 'Changes in personal relationships: how social contexts affect the emergence and discontinuation of relationships', Social Networks, 37, 65-80, doi: 10.1016/j.socnet.2013.12.003.

Moore, G. (1990) 'Structural determinants of men's and women's personal networks', American Sociological Review, 55 (5), 726-35, available at: http://goo.gl/VZtMNq.

Morosanu, L. (2013) 'Between fragmented ties and "soul friendships": the cross-border social connections of young Romanians in London', Journal of Ethnic and Migration Studies, 39 (3), 353-72, doi: 10.1080/1369183X.2013.733858.

Mulder, C. H. and T. J. Cooke (2009) 'Family ties and residential locations', Population, Space and Place, 15 (4), 299-304, doi: 10.1002/psp.556.

Nee, V. and J. Sanders (2001) 'Understanding the diversity of immigrant incorporation: a forms-ofcapital model', Ethnic and Racial Studies, 24 (3), 386-411, doi: 10.1080/01419870020036710.

Petersen, W. (1958) 'A general typology of migration', American Sociological Review, 23 (3), 256-66, doi: 10.2307/2089239.

Polek, E., J. Wöhrle and P. J. van Oudenhoven (2010) 'The role of attachment styles, perceived discrimination, and cultural distance in adjustment of German and eastern European immigrants in the Netherlands', Cross-Cultural Research, 44 (1), 60-88, doi: 10.1177/ 1069397109352779.

Portes, A. and J. Sensenbrenner (1993) 'Embeddedness and immigration: notes on the social determinants of economic action', American Journal of Sociology, 98 (6), 1320-50, doi: $10.1086 / 230191$.

Putnam, R. D. (2000) Bowling alone: the collapse and revival of American community, New York: Simon \& Schuster.

Recchi, E. (2008) 'Cross-state mobility in the EU: trends, puzzles and consequences', European Societies, 10 (2), 197-224, doi: 10.1080/14616690701835287.

Recchi, E. (2015) Mobile Europe: the theory and practice of free movement in the EU, Basingstoke, Palgrave Macmillan.

Roberts, S. G. B., R. I. M. Dunbar, T. V. Pollet and T. Kuppens (2009) 'Exploring variation in active network size: constraints and ego characteristics', Social Networks, 31 (2), 138-46, doi: 10.1016/j.socnet.2008.12.002.

Rodríguez, V. and C. Egea (2006) 'Return and the social environment of Andalusian emigrants in Europe', Journal of Ethnic and Migration Studies, 32 (8), 1377-93, doi: 10.1080/1369 1830600928771.

Roggeveen, S. and M. van Meeteren (2013) 'Beyond community: an analysis of social capital and the social networks of Brazilian migrants in Amsterdam', Current Sociology, 61 (7), 1078-96, doi: 10.1177/0011392113495862.

Rooyackers, I. N., H. A. G. de Valk and E. M. Merz (2014) 'Mother-child relations in adulthood: immigrant and nonimmigrant families in the Netherlands', Journal of Cross-Cultural Psychology, 45 (4), 569-86, doi: 10.1177/0022022113519856.

Rossi, A. and P. Rossi (1990) Of human bonding: parent-child relationships across the life course, New York: Aldine de Gruyter.

Ryan, L. (2007) 'Migrant women, social networks and motherhood: the experiences of Irish nurses in Britain', Sociology, 41 (2), 295-312, doi: 10.1177/0038038507074975.

Ryan, L. (2011) 'Migrants' social networks and weak ties: accessing resources and constructing relationships post-migration', The Sociological Review, 59 (4), 707-24, doi: 10.1111/j.1467954X.2011.02030.x.

Ryan, L. and J. Mulholland (2014a) 'Trading places: French highly skilled migrants negotiating mobility and emplacement in London', Journal of Ethnic and Migration Studies, 40 (4), 584-600, doi: 10.1080/1369183X.2013.787514. 
Ryan, L. and J. Mulholland (2014b) 'French connections: the networking strategies of French highly skilled migrants in London', Global Networks, 14 (2), 148-66, doi: 10.1111/glob.12038.

Ryan, L. and J. Mulholland (2014c) "WWives are the route to social life": an analysis of family life and networking amongst highly skilled migrants in London', Sociology, 48 (2), 251-67, doi: $10.1177 / 0038038512475109$.

Ryan, L., R. Sales, M. Tilki and B. Siara (2008) 'Social networks, social support and social capital: the experiences of recent Polish migrants in London', Sociology, 42 (4), 672-90, doi: $10.1177 / 0038038508091622$.

Santacreu, O., E. Baldoni and M. C. Albert (2009) 'Deciding to move: migration projects in an integrating Europe', in E. Recchi and A. Favell (eds), Pioneers of European integration: $£ £$ in the EU, Cheltenham: Edward Elgar, 52-71.

Schaeffer, M. (2013) 'Inter-ethnic neighbourhood acquaintances of migrants and natives in Germany: on the brokering roles of inter-ethnic partners and children', Journal of Ethnic and Migration Studies, 39 (8), 1219-40, doi: 10.1080/1369183X.2013.778147.

Schweizer, T., M. Schnegg and S. Berzborn (1998) 'Personal networks and social support in a multiethnic community of southern California', Social Networks, 20 (1), 1-21, doi: 10.1016/ S0378-8733(96)00304-8.

Silverstein, M. and A. Marenco (2001) 'How Americans enact the grandparent role across the family life course', Journal of Family Issues, 22 (4), 493-522, doi: 10.1177/019251301022004006.

Thomas, W. I. and F. Znaniecki (1918) The Polish peasant in Europe and America: monograph of an immigrant group, Boston: Gorham Press.

Van Der Pers, M., C. H. Mulder and N. Steverink (2015) 'Geographic proximity of adult children and the well-being of older persons', Research on Aging, 37 (5), 524-51, doi: 10.1177/ 0164027514545482 .

Van Mol, C. (2014) Intra-European student mobility in international higher education circuits: Europe on the move, Basingstoke: Palgrave Macmillan.

Van Mol, C. and J. Michielsen (2015) 'The reconstruction of a social network abroad: an analysis of the interaction patterns of Erasmus students', Mobilities, 10 (3), 423-44, doi: 10.1080/ 17450101.2013 .874837$.

van Tubergen, F. (2014) 'Size and socio-economic resources of core discussion networks in the Netherlands: differences by national-origin group and immigrant generation', Ethnic and Racial Studies, 37 (6), 1020-42, doi: 10.1080/01419870.2012.734390.

Vervoort, M., H. Flap and J. Dagevos (2011) 'The Ethnic Composition of the Neighbourhood and Ethnic Minorities' Social Contacts: Three Unresolved Issues', European Sociological Review, 27 (5), 586-605, doi: 10.1093/esr/jcq029.

Verweij, A. and M. Kalmijn (2004) 'Op bezoek bij familie en schoonfamilie: een vergelijking van bezoekfrequenties gebaseerd op gegevens over gehuwde en samenwonende paren', Mens \& Maatschappij, 79 (1), 66-88, available at: http://goo.gl/clYLWd.

Verwiebe, R. (2014) 'Why do Europeans migrate to Berlin? Social-structural differences for Italian, British, French and Polish nationals in the period between 1980 and 2002', International Migration, 52 (4), 209-30, doi: 10.1111/j.1468-2435.2010.00663.x

Viry, G. (2012) 'Residential mobility and the spatial dispersion of personal networks: effects on social support', Social Networks, 34 (1), 59-72, doi: 10.1016/j.socnet.2011.07.003.

Völker, B., F. Pinkster and H. Flap (2008) 'Inequality in social capital between migrants and natives in the Netherlands', Kölner Zeitschrift für Soziologie und Sozialpsychologie, 48, 325-50.

Wellman, B., R. Y. L. Wong, D. Tindall and N. Nazer (1997) 'A decade of network change: turnover, persistence and stability in personal communities', Social Networks, 19 (1), 27-50, doi: 10.1016/S0378-8733(96)00289-4.

Widmer, E. D. (2004) 'Couples and their networks', in J. Scott, J. Treas and M. Richards (eds) The Blackwell companion to the sociology of families, Oxford: Blackwell.

Zontini, E. (2004) Italian families and social capital: rituals and the provision of care in British-Italian transnational families, London: London South Bank University. 